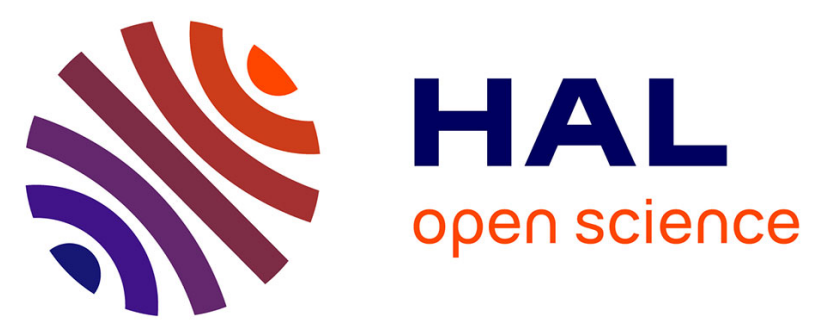

\title{
The status of strontium in biological apatites: an XANES/EXAFS investigation
}

Dominique Bazin, Arnaud Dessombz, Christelle Nguyen, Hang Korng Ea, Frédéric Lioté, John Rehr, Christine Chappard, Stephan Rouzière, Dominique Thiaudière, Solen Reguer, et al.

\section{To cite this version:}

Dominique Bazin, Arnaud Dessombz, Christelle Nguyen, Hang Korng Ea, Frédéric Lioté, et al.. The status of strontium in biological apatites: an XANES/EXAFS investigation. Journal of Synchrotron Radiation, 2014, 21 (Pt 1), pp.136-42. 10.1107/S1600577513023771 . hal-00994761

\section{HAL Id: hal-00994761 https://hal.sorbonne-universite.fr/hal-00994761}

Submitted on 27 May 2014

HAL is a multi-disciplinary open access archive for the deposit and dissemination of scientific research documents, whether they are published or not. The documents may come from teaching and research institutions in France or abroad, or from public or private research centers.
L'archive ouverte pluridisciplinaire HAL, est destinée au dépôt et à la diffusion de documents scientifiques de niveau recherche, publiés ou non, émanant des établissements d'enseignement et de recherche français ou étrangers, des laboratoires publics ou privés. 
Journal of

Synchrotron

Radiation

ISSN 1600-5775

\section{The status of strontium in biological apatites: an XANES/EXAFS investigation}

\section{Dominique Bazin, Arnaud Dessombz, Christelle Nguyen, Hang Korng Ea, Frédéric Lioté, John Rehr, Christine Chappard, Stephan Rouzière, Dominique Thiaudière, Solen Reguer and Michel Daudon}

J. Synchrotron Rad. (2014). 21, 136-142

Copyright (C) International Union of Crystallography

Author(s) of this paper may load this reprint on their own web site or institutional repository provided that this cover page is retained. Republication of this article or its storage in electronic databases other than as specified above is not permitted without prior permission in writing from the IUCr.

For further information see http://journals.iucr.org/services/authorrights.html

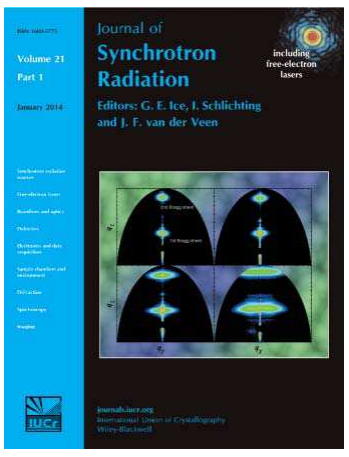

Synchrotron radiation research is rapidly expanding with many new sources of radiation being created globally. Synchrotron radiation plays a leading role in pure science and in emerging technologies. The Journal of Synchrotron Radiation provides comprehensive coverage of the entire field of synchrotron radiation research including instrumentation, theory, computing and scientific applications in areas such as biology, nanoscience and materials science. Rapid publication ensures an up-to-date information resource for scientists and engineers in the field.

Crystallography Journals Online is available from journals.iucr.org 
Journal of

Synchrotron

Radiation

ISSN 1600-5775

Received 15 July 2013

Accepted 22 August 2013

(C) 2014 International Union of Crystallography

\section{The status of strontium in biological apatites: an XANES/EXAFS investigation}

\author{
Dominique Bazin, ${ }^{a} *$ Arnaud Dessombz, ${ }^{b}$ Christelle Nguyen, ${ }^{c, d}$ Hang Korng Ea, ${ }^{c, e}$ \\ Frédéric Lioté, ${ }^{\mathrm{c}, \mathrm{e}}$ John Rehr, ${ }^{\mathrm{f}}$ Christine Chappard, ${ }^{\mathrm{g}}$ Stephan Rouzière, \\ Dominique Thiaudière, ${ }^{\mathrm{h}}$ Solen Reguer $^{\mathrm{h}}$ and Michel Daudon ${ }^{\mathrm{i}}$
}

\begin{abstract}
${ }^{a}$ CNRS-LCMCP-UPMC, Collège de France, 11 place Marcelin Berthelot, 75231 Paris Cedex 05, France, 'baboratoire de Physique des Solides, Université Paris XI, Bâtiment 510, 91405 Orsay, France, ' INSERM, UMR-S 606, Lariboisière Hospital, F-75010 Paris, France, 'Université Paris Diderot, Sorbonne Paris Cité, F-75205 Paris, France, ${ }^{\mathbf{e}}$ Rheumatology Department, AP-HP, Hôpital Lariboisière, Centre Viggo Petersen, Pôle Appareil Locomoteur, F-75010 Paris, France, fDepartment of Physics, University of Washington, Seattle, WA 98195, USA, ${ }^{\mathbf{g}}$ B2OA, UMR 7052 CNRS, Université Paris Diderot, 10 avenue de Verdun, F-75010 Paris, France, hynchrotron SOLEIL, L'Orme des Merisiers, Saint-Aubin, BP 48, 91192 Gif-sur-Yvette, France, and 'Service d'Explorations Fonctionnelles, AP-HP, Hôpital Tenon, 4 rue de la Chine, F-75020 Paris, France. *E-mail: dominique.bazin@u-psud.fr
\end{abstract}

Osteoporosis represents a major public health problem through its association with fragility fractures. The public health burden of osteoporotic fractures will rise in future generations, due in part to an increase in life expectancy. Strontium-based drugs have been shown to increase bone mass in postmenopausal osteoporosis patients and to reduce fracture risk but the molecular mechanisms of the action of these Sr-based drugs are not totally elucidated. The local environment of $\mathrm{Sr}^{2+}$ cations in biological apatites present in pathological and physiological calcifications in patients without such Sr-based drugs has been assessed. In this investigation, X-ray absorption spectra have been collected for 17 pathological and physiological calcifications. These experimental data have been combined with a set of numerical simulations using the ab initio FEFF9 X-ray spectroscopy program which takes into account possible distortion and $\mathrm{Ca} / \mathrm{Sr}$ substitution in the environment of the $\mathrm{Sr}^{2+}$ cations. For selected samples, Fourier transforms of the EXAFS modulations have been performed. The complete set of experimental data collected on 17 samples indicates that there is no relationship between the nature of the calcification (physiological and pathological) and the adsorption mode of $\mathrm{Sr}^{2+}$ cations (simple adsorption or insertion). Such structural considerations have medical implications. Pathological and physiological calcifications correspond to two very different preparation procedures but are associated with the same localization of $\mathrm{Sr}^{2+}$ versus apatite crystals. Based on this study, it seems that for supplementation of $\mathrm{Sr}$ at low concentration, $\mathrm{Sr}^{2+}$ cations will be localized into the apatite network.

Keywords: Ca phosphate apatites; physiological calcifications; pathological calcifications; Fourier transform infrared spectroscopy; X-ray absorption spectroscopy; strontium environment.

\section{Introduction}

As underlined in recent reviews and publications, osteoporosis, which mainly occurs during aging and after menopause, is characterized by an increase in bone fragility due to low bone mass and deterioration of bone quality (Meunier et al., 2004; Rochefort et al., 2010; Moyad, 2003). Femoral neck, humeral and vertebral fractures are the hallmark of severe osteoporosis, although fracture risk in other bones is also increased in the presence of osteoporosis.

Current therapy for osteoporosis includes dietary supplementation of calcium and vitamin $\mathrm{D}$, in addition to treatment with estrogens, oral or parenteral bisphosphonates, selective estrogen receptor modulators, teriparatide, strontium ranelate or, even more recently, denosumab, according to National recommendations and rules (Pinkerton \& Dalkin, 2007; 
Kanakamani \& Tandon, 2008). The only strontium-based drug, strontium ranelate, has also shown anti-fracture efficacy in the treatment of postmenopausal osteoporosis (Marie, 2005; Cortet, 2011).

A starting point for understanding the role of strontium from a physicochemistry point of view is given by a description of the local order around $\mathrm{Sr}$ atoms in order to assess its localization versus hydroxyapatite (HAP), the mineral part of the bone (Bazin et al., 2009a). The different structural hypotheses (Fig. 1) regarding the localization of $\mathrm{Sr}^{2+}$ cations in bone which take into account the physicochemistry of biological apatite have been presented previously (Bazin et al., 2011; Elliott, 1994). These structural hypotheses take into account the different structural specificities of biological apatites (Vallet-Reg1 \& Gonzalez-Calbet, 2002; Penel et al., 1998; Rey et al., 1995, 2007).

The first structural hypothesis corresponds to $\mathrm{Sr}^{2+}$ cations surrounded only by oxygen atoms which are adsorbed at the surface of collagen or apatite (hypothesis 1 in Fig. 1). Note that $\mathrm{Sr}^{2+}$ cations may have various coordination numbers with oxygen in solids and aqueous solutions (Persson et al., 1995; O'Day et al., 2000). $\mathrm{Sr}^{2+}$ cations could also be engaged in the hydrated poorly crystalline apatite region present at the surface of calcium phosphate nanocrystals (hypothesis 2 in Fig. 1). Finally, a substitution could occur between $\mathrm{Sr}^{2+}$ cations and $\mathrm{Ca}^{2+}$ cations inside $\mathrm{Ca}$ phosphate nanocrystals on either crystallographic site (I) or (II) (hypothesis 3 in Fig. 1).

As mentioned previously, we should recognize that, either for nanometer-scale materials or due to the low content of trace elements inside physiological or pathological apatites, diffraction techniques have to be completed by a local structural investigation through X-ray absorption spectroscopy (XAS) (Guinier, 1956; Li et al., 2010; Sayers et al., 1970; Bazin et al., 2006, 2012; Bazin \& Daudon, 2012). It should be noted that XAS is insensitive to polydispersity (Moonen et al., 1995). As emphasized previously (Bazin et al., 2012), XAS encompasses both X-ray absorption near-edge structure (XANES) and extended X-ray absorption fine structure (EXAFS). Several previous investigations have shown that XAS brings invaluable structural and electronic information regarding the local environment of specific elements such as $\mathrm{Ca}^{2+}$ (Eichert et al., 2005; Sepulcre et al., 2004; Carpentier et al., 2010; Laur-

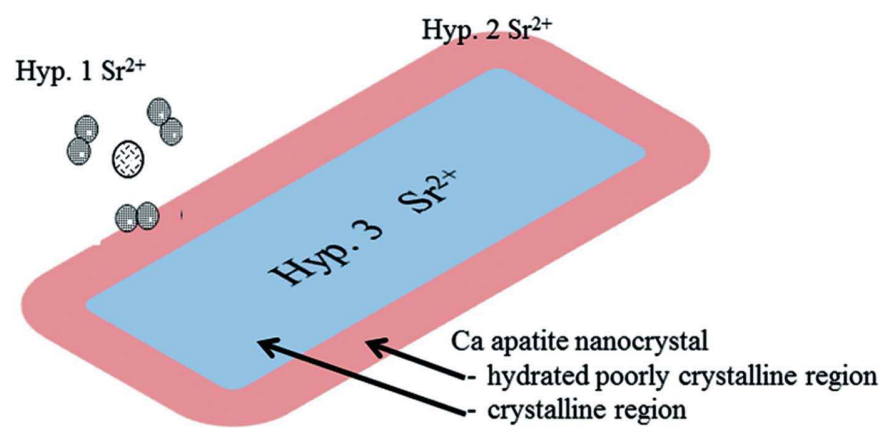

Figure 1

Schematic representation of the three structural hypotheses assessed in this study regarding the localization of $\mathrm{Sr}^{2+}$ cations in HAP.
Table 1

Composition given by FTIR and the origin of the calcifications.

$\mathrm{CA}=$ carbonated calcium hydroxylapatite MAP $=$ magnesium ammonium phosphate (struvite); Prot = protein; $\mathrm{C} 1=$ whewellite; $\mathrm{C} 2$ = weddellite; $\mathrm{ACCP}$ $=$ amorphous carbonated calcium phosphate; $\mathrm{TGL}=$ triglyceride; $\mathrm{WK}=$ whitlockite.

\begin{tabular}{lll}
\hline Sample & Origin & Composition \\
\hline N15116 & Kidney & 87\% CA, 7\% Prot, 4\% C2, 2\% C1 \\
N15203 & Kidney & $91 \%$ CA, 6\% Prot, 3\% C1 \\
N13083 & Kidney & $90 \%$ CA, 6\% Prot, 4\% C1 \\
N3289 & Prostate & $75 \%$ CA, 14\% C2, 9\% C1, 1\% MAP, 1\% Prot \\
N60592 & Prostate & $74 \%$ CA, 9\% Prot, 7\% WK, 5\% ACCP, 3\% C1, 2\% C2 \\
N11823 & Kidney & 66\% CA, 30\% ACCP, 4\% Prot \\
N13066 & Kidney & $79 \%$ CA, 15\% ACCP, 4\% Prot, 2\% C1 \\
N13086 & Prostate & $84 \%$ CA, 12\% Prot, 4\% C1 \\
N15048 & Kidney & $87 \%$ CA, 6\% C1, 4\% C2, 3\% Prot \\
N17161 & Bladder & $61 \%$ CA, 30\% ACCP, 8\% Prot, 1\% C1 \\
\hline
\end{tabular}

encin et al., 2011) or trace elements such as $\mathrm{Zn}^{2+}$ (Bazin et al., 2009b; Yu et al., 2009; Tang et al., 2009; Dessombz et al., 2013) or $\mathrm{Sr}^{2+}$ (Bazin et al., 2011; Palmer et al., 1996; McKeown et al., 2003; Seward et al., 1999; Murata et al., 2012; Yachandra \& Yano, 2011; Martin et al., 2012) in pathological calcifications or in other materials.

In a previous study (Bazin et al., 2011), the XANES part of the absorption spectra as well as numerical simulations using the ab initio FEFF9 X-ray spectroscopy program (Rehr et al., 2009; Bazin \& Rehr, 2003) have been used to assess the localization of $\mathrm{Sr}^{2+}$ cations in these biological apatites. This investigation seems to indicate that a simple adsorption of $\mathrm{Sr}^{2+}$ cations exists in the case of pathological calcifications while an insertion of $\mathrm{Sr}^{2+}$ is observed at least for one physiological calcification (bone 1). For the other three physiological samples, bones 2, 3 and 4, the evidence is much weaker.

In this investigation, 17 pathological and physiological calcifications have been considered. A new set of numerical simulations using the $a b$ initio FEFF9 X-ray spectroscopy program have been performed in order to take into account local lattice distortion. Moreover, for selected samples, Fourier transforms of the EXAFS modulations have been performed. The ultimate aim of this study is to confirm, through X-ray absorption experiments at the $\mathrm{Sr} K$-edge and numerical simulations, the possible relationship between the adsorption mode of $\mathrm{Sr}^{2+}$ cations and the nature of the calcification.

\section{Materials and methods}

The biological samples (Table 1) analysed in the present investigation came from two different hospitals. More precisely, kidney stones and bones were obtained from Necker Hospital and Lariboisière Hospital (both Paris), respectively. Regarding an ethics statement, we followed the usual procedures (Dessombz et al., 2011, 2012). All participants gave verbal consent, documented by the researchers, for use of their samples. The samples were examined without knowledge of the name of the patient or other identifying data. Ethical approval for the study was obtained from the ethics committee 
of Tenon and Lariboisiere Hospital. The investigation conformed to the principles of the Declaration of Helsinki.

All of the samples have been characterized by Fourier transform infrared (FTIR) spectroscopy using the Vector 22 (Bruker Spectrospin, Wissembourg, France) FTIR spectrometer. Data were collected in the absorption mode between 4000 and $400 \mathrm{~cm}^{-1}$ with a resolution of $4 \mathrm{~cm}^{-1}$ (Estepa \& Daudon, 1997). Compositions for the pathological calcifications given by FTIR spectroscopy are gathered in Table 1. For all the calcifications, apatite is the major component, and also for the bones (bone samples 1 to 7 ).

All of the samples were investigated on the DIFFABS beamline at synchrotron SOLEIL (France). In this experimental set-up, it is possible to combine micro-X-ray scattering, micro-X-ray absorption and micro-X-ray fluorescence spectroscopies. SOLEIL is running at $2.75 \mathrm{GeV}$ with an average current of $400 \mathrm{~mA}$ in the new top-up mode. Details regarding the monochromator, the mirror as well as the devices used for the detection on DIFFABS, are gathered in previous studies (Bazin et al., 2008; Nguyen et al., 2011). In our case, the beamline was optimized in order to measure XANES spectra at the $\mathrm{Sr} K$-edge. The energy range for the spectra acquisition was selected between 16000 and $16200 \mathrm{eV}$, with an energy step of $0.5 \mathrm{eV}$ and a $3 \mathrm{~s}$ acquisition time. The measurements were made in the fluorescence mode, using a silicon drift detector. The size of the beam was determined by a set of slits (100$500 \mu \mathrm{m})$.

Regarding the analysis of the EXAFS modulations, data treatment was carried out using standard procedures (Sayers et al., 1970, 1971). The background contribution, originating from the pre-edge region, was extrapolated using the Victoreen relationship and then subtracted from the experimental data. The smooth atom-like contribution $\mu_{0}(k)$ was obtained by cubic-spline fitting. The edge energy, $E_{0}$, was arbitrarily chosen at the edge inflection. The EXAFS function, multiplied by $k$, was a Fourier transform (FT) in the photoelectron wavevector range (2.33-9.00 $\left.\AA^{-1}\right)$ after the application of a Kaiser window. Such analysis parameters have been selected in order to compare our results with a previous investigation (Terra et al., 2009). In this work, all FTs are calculated and presented without phase correction.

\section{Results}

All the XANES spectra collected at the $\mathrm{Sr} K$-edge on the different samples have been plotted in Fig. 2. The spectra are classified depending on the type of calcifications (physiological/pathological). For some of these experimental data, a small feature (see arrows in Fig. 2) exists (at $16135 \mathrm{eV}$ ) just after the white line which reflects the effective charge of $\mathrm{Sr}^{2+}$ ions $\left(4 d^{0}\right.$ electron configuration). We can already underline the fact that such a feature seems to be present in physiological as well as in pathological calcifications.

A set of numerical simulations have been performed regarding the local environment of $\operatorname{Sr}(\mathrm{I})^{2+}$. For the sake of clarity, the labels (see Fig. 3) which indicate the Sr environment are similar to the ones previously used (Bazin et al.,

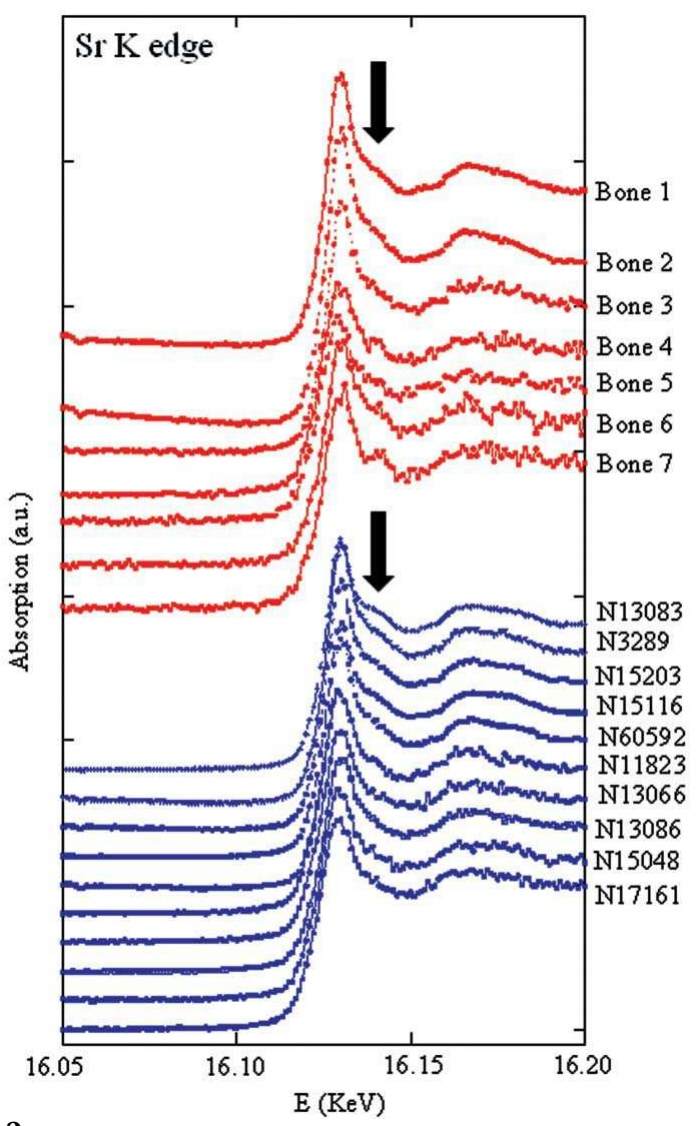

Figure 2

XANES part of X-ray absorption spectra collected at the $\mathrm{Sr} K$-edge for different physiological (in red) and pathological (in blue) calcifications.

2011). For this new set of numerical calculations, different structural configurations have been taken into account including cations vacancies (Fig. 4), Ca/Sr substitutions (Fig. 5) and the local lattice distortion (Fig. 6).

Regarding the analysis of the EXAFS modulations beyond the $\mathrm{Sr} K$-edge, a typical example of the X-ray absorption spectrum is shown in Fig. 7. Selected EXAFS oscillations have been plotted and have been compared with FEFF simulations and other experimental results in Fig. 8.

\section{Discussion}

Strontium-substituted apatites are used in the treatment of postmenopausal osteoporosis and have different applications owing to their antimicrobial activity (Ravi et al., 2012), blueluminescent composition (Zhang et al., 2009) and radiopacity (Romieu et al., 2006). This set of potential industrial applications has motivated different investigations regarding the interaction of $\mathrm{Sr}^{2+}$ cations and different compounds such as calcium hydrogenophosphate dehydrate, $\mathrm{Na}_{2} \mathrm{O}-\mathrm{CaO}-\mathrm{P}_{2} \mathrm{O}_{5}-$ $\mathrm{SiO}_{2}$ glasses (O'Donnel \& Hill, 2010) or Ca phosphate (Korbas et al., 2004).

Different characterization techniques exist to assess the localization of bivalent cations in the inorganic matrix. Among them are NMR (Bonhomme et al., 2012; Pizzala et al., 2009), FTIR spectroscopy (Bigi et al., 2007), microRaman (Gomes et 


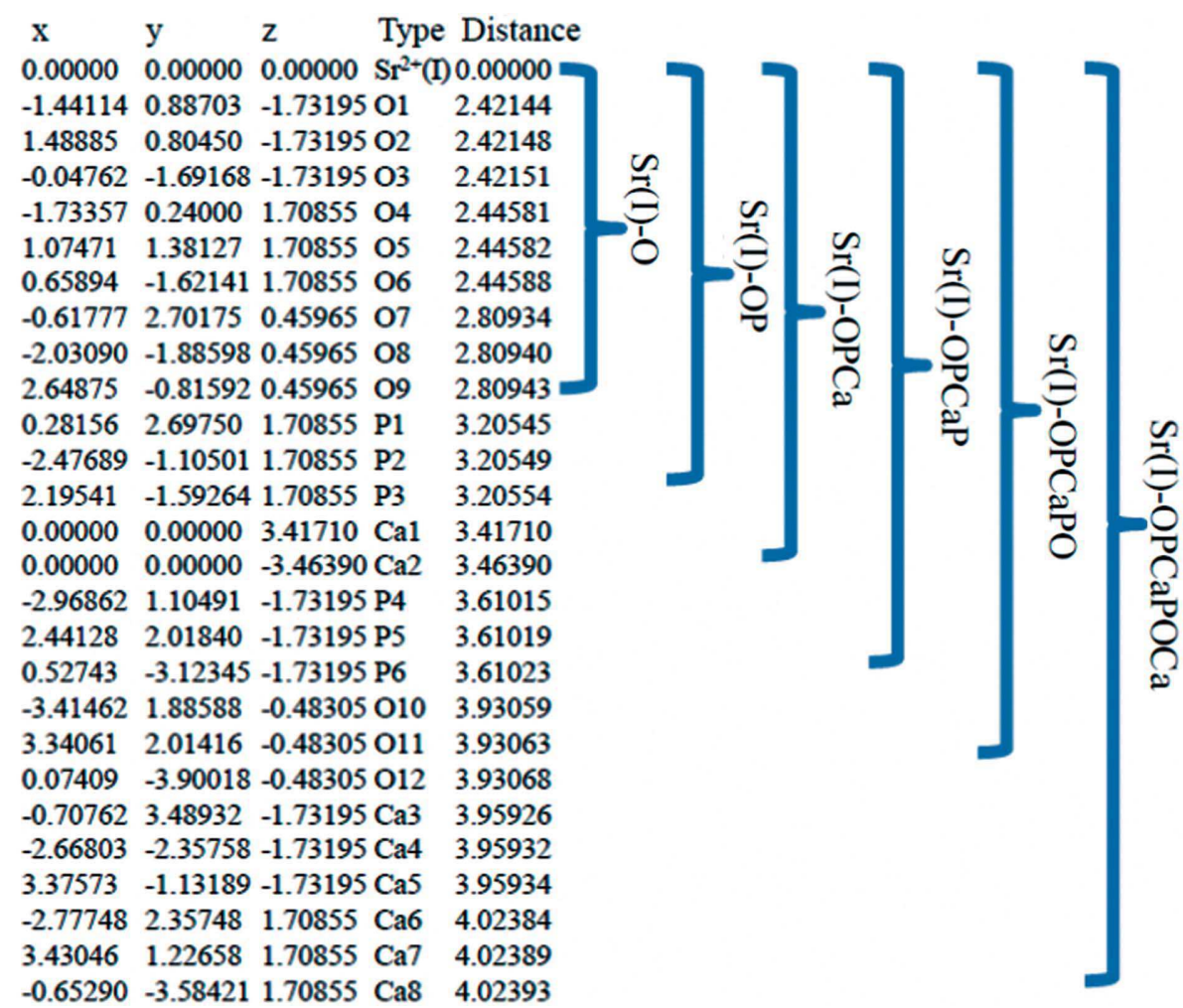

Figure 3

Details regarding the spatial repartition of atoms around $\mathrm{Sr}^{2+}$ cations located in site (I).

obtained (Mimura et al., 2012). At this point we have to underline that more classical chemical techniques such as solid titration also give quite interesting results. For example, the increase in solubility with strontium content has been interpreted as a destabilization of the crystal structure (Pan et al., 2009a).

Several publications show that the incorporation of foreign ions into the HAP structure can affect its crystallinity, morphology, lattice parameters and stability (Ibrahim et al., 2011). All these structural parameters may have significant medical implications. For example, we have already discussed the modulations of crystal morphology with the nature of the disease (Daudon et al., 2008, 2009). Among the bivalent cations, $\mathrm{Sr}^{2+}, \mathrm{Cd}^{2+}$ and $\mathrm{Pb}^{2+}$ can replace $\mathrm{Ca}^{2+}$ over the whole range of compositions (Bigi et al., 1995). Several other ions, usually with an ionic radius smaller than that of $\mathrm{Ca}^{2+}$, such as $\mathrm{Mg}^{2+}, \mathrm{Mn}^{2+}$, $\mathrm{Fe}^{2+}, \mathrm{Co}^{2+}$ and $\mathrm{Ni}^{2+}$, are known to inhibit the synthesis of HAP and promote the formation of $\beta$-tricalcium phosphate. Regarding the interaction of

al., 2012) small-angle X-ray scattering, X-ray diffraction (Li et al., 2010), neutron powder diffraction (Gomes et al., 2011) as well as techniques specific to synchrotron radiation such as anomalous wide-angle X-ray scattering (Revel et al., 2000) and X-ray absorption spectroscopy. Recently, an overview of the most important microanalytical techniques currently available for the in situ detection of trace metals in cells and tissues has been published (McRae et al., 2009). An X-ray beam focused in one direction to a width of $7 \mathrm{~nm}$ at $20 \mathrm{keV}$ has been

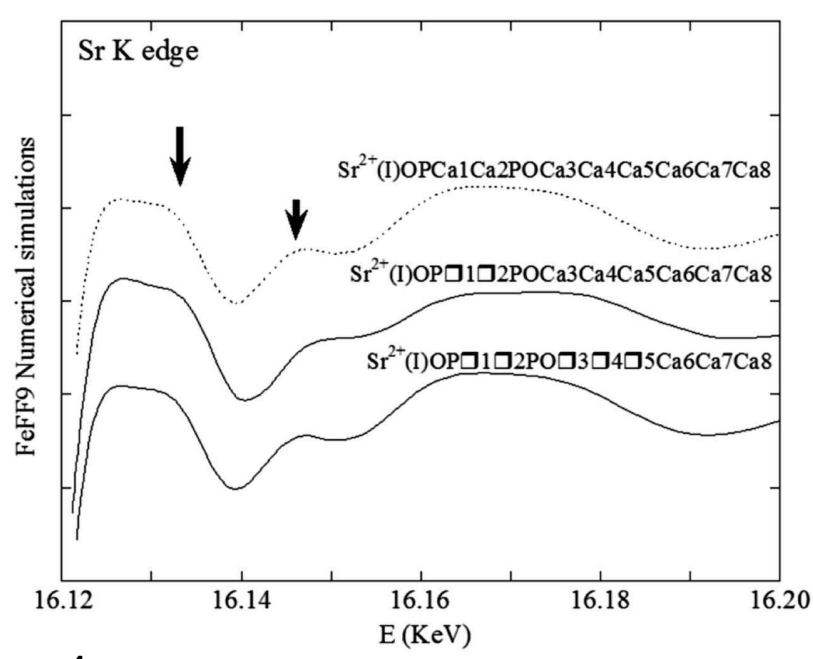

Figure 4

FEFF simulations taking into account the presence of cationic vacancies (squares) for the environment of $\mathrm{Sr}^{2+}(\mathrm{I})$. The positions of vacancies in the different simulations have been given.
Sr with apatite, no significant incorporation of strontium in the resulting apatite was detected for $[\mathrm{Sr}]<0.1 \mathrm{mM}$, but crystal morphology changed dramatically and crystallinity increased for $[\mathrm{Sr}] \geq 0.3 \mathrm{~m} M$ due to the formation of strontium-substituted apatite, with substitution increasing with an increase of solution (Pan et al., 2009b). Also, from the kinetics point of view, it has been reported that the presence of strontium retarded the crystal growth of HAP on seed crystals (Rokidi \&

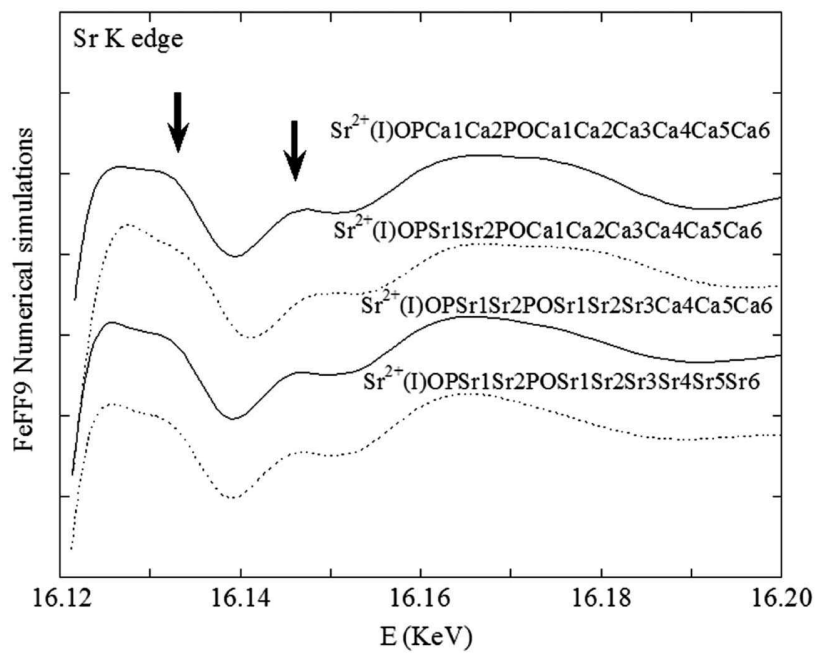

Figure 5

FEFF simulations taking into account $\mathrm{Ca} / \mathrm{Sr}$ substitution in the environment of $\mathrm{Sr}^{2+}(\mathrm{I})$. The different substitutions taken into account in the simulations have been given. 


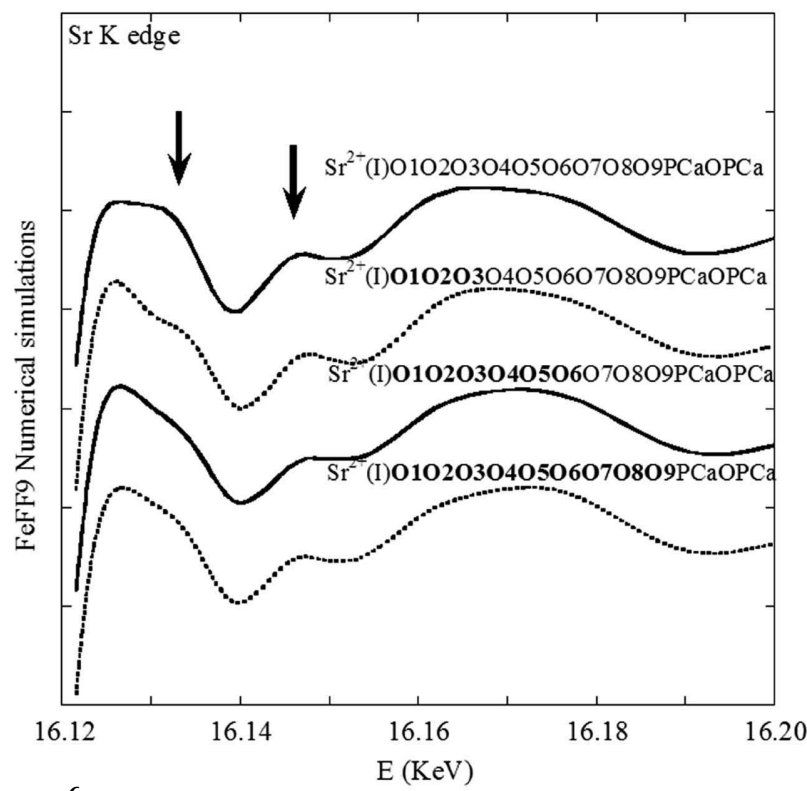

Figure 6

FEFF simulations taking into account possible distortion in the environment of $\mathrm{Sr}^{2+}(\mathrm{I})$. More precisely, cartesien coordinates of oxygen atoms in bold have been changed.

Koutsoukos, 2012). Previous studies clearly indicate that the insertion of cations in apatite is a complex process which is sensitive to preparation methods (Bazin et al., 2011).

In this investigation, we focus on the localization of $\mathrm{Sr}^{2+}$ cations in $\mathrm{Ca}$ apatite. It should be noted that such measurements can be performed directly on the sample with minimal preparation. In order to confirm the possible relationship between the adsorption mode of $\mathrm{Sr}^{2+}$ cations (adsorbed at the surface or inserted inside the Ca apatite crystal) and the nature of the calcification (physiological or pathological calcifications), X-ray absorption experiments at the $\mathrm{Sr} K$-edge as well as $a b$ initio numerical simulations have been performed (Bazin et al., 2011). At first, the new set of XANES data collected for 17 samples (Fig. 2) seems to indicate that such a relationship is not obvious. The XANES data corresponding to pathological and physiological calcifications are quite similar. A small feature related to the adsorption mode of $\mathrm{Sr}^{2+}$ cations exists (at $16135 \mathrm{eV}$ ) just after the white line and before the first oscillation is observed for one sample (bone 1) while for three physiological samples (bones 2-4) the evidence is much weaker (Fig. 2).

Regarding the numerical simulations of the XANES part of the absorption spectra, in this new set of $a b$ initio calculations several structural configurations have been taken into account, including a possible local lattice distor-

Figure 8

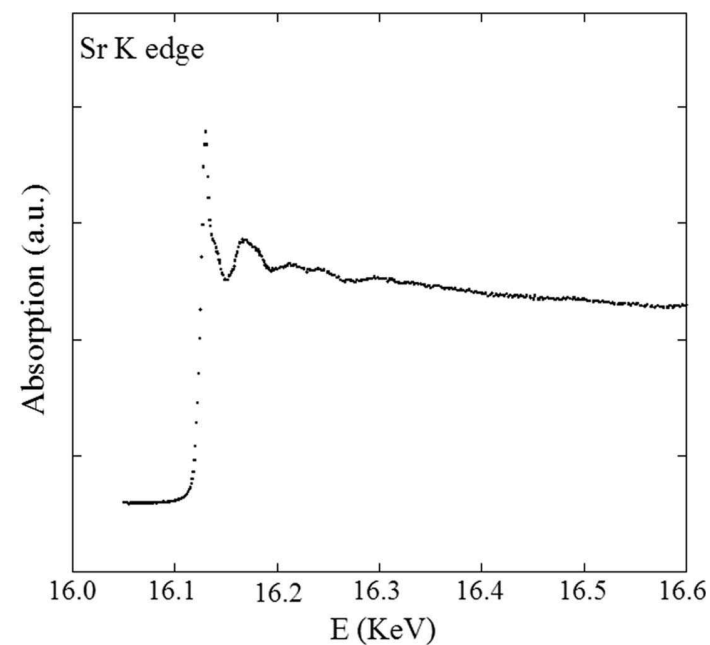

Figure 7

X-ray absorption spectra collected beyond the $\mathrm{Sr} K$-edge.

tion around the $\mathrm{Sr}^{2+}$ cations (Fig. 6), the existence of $\mathrm{Ca} / \mathrm{Sr}$ substitutions (Fig. 5) or cations vacancies (Fig. 4). As observed, the existence of the small feature present just after the white line seems to be not significantly affected by such structural modifications. We can underline the fact that the local environment of $\operatorname{Sr}(\mathrm{I})^{2+}$ is already quite distorted and thus structural modifications such as modification of the Cartesian coordinates of oxygen atoms around $\mathrm{Sr}^{2+}$ cations, $\mathrm{Ca} / \mathrm{Sr}$ substitution or cation vacancies seem to have a weak influence on the XANES part of the absorption spectra. Now we have to gather this new set of simulations with the previous one. The feature apparent after the white line is visible only for $\mathrm{Sr}^{2+}$ cations present inside the apatite network and disappears for

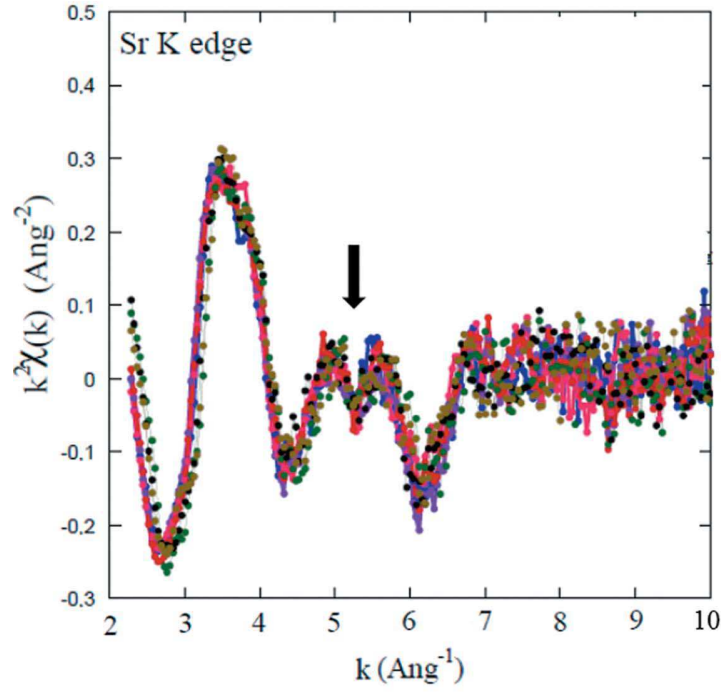

(a)

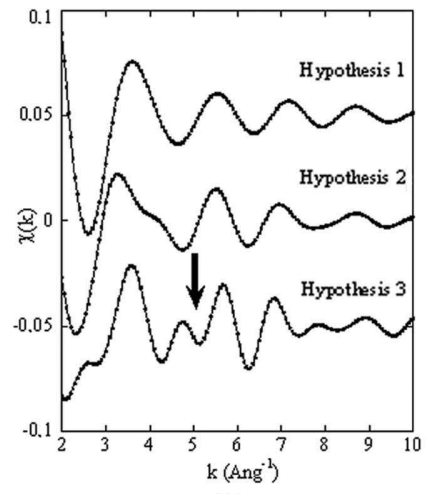

(b)

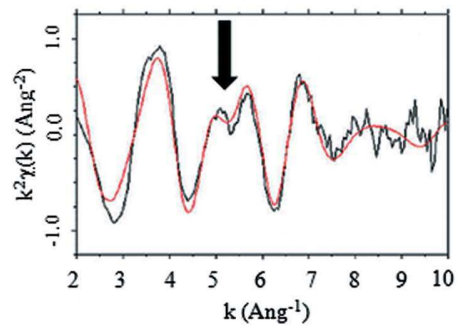

(c)

(a) EXAFS modulations after the Sr $K$-edge for different samples. (b) EXAFS modulations as calculated for the three different hypotheses. (c) EXAFS modulations as measured in the case of hypothesis 3 (Terra et al., 2009). 
$\mathrm{Sr}^{2+}$ cations surrounded by oxygen and phosphorus atoms. As underlined previously (Bazin et al., 2011), such a feature is not always observed for $\mathrm{Sr}^{2+}$ cations present inside the apatite network.

Regarding the EXAFS data measured after the $\mathrm{Sr} K$-edge, the modulations are very similar to ones previously measured (Terra et al., 2009; Korbas et al., 2004) in which $\mathrm{Sr}^{2+}$ cations are located inside the apatite crystal (Fig. 1). In order to show what differences in $\mathrm{Sr}$ signal would be expected for $\mathrm{Sr}$ in different local environments, we have calculated the EXAFS modulations for the different structural possibilities (Fig. 8b). It is quite clear that our experimental measurements correspond to a substitution between $\mathrm{Sr}^{2+}$ cations and $\mathrm{Ca}^{2+}$ cations inside Ca phosphate nanocrystals (see arrow in Figs. $8 a, 8 b$ and $8 c$ ). Such data, in line with previous experiments (Fig. 8c), indicate clearly the existence of $\mathrm{Sr}-\mathrm{Ca}$ or $\mathrm{Sr}-\mathrm{Sr}$ interatomic distances after the contribution coming from oxygen and phosphorus atoms for the different samples selected in this investigation. There is no significant structural difference between physiological and pathological calcifications regarding the localization of $\mathrm{Sr}^{2+}$ cations.

Such structural considerations may have medical implications. In osteoporosis, clinical studies indicate that strontium ranelate increases bone formation and tends to decrease bone resorption in treated osteoporotic patients (Marie, 2007). Thus, different investigations have been performed to assess the effect of strontium incorporation into hydroxyapatite nanocrystals on bone cell response. For example, different experiments (Capuccini et al., 2009) indicate that strontium stimulates osteoblast activity and exerts its inhibitory effect on osteoclast proliferation even when incorporated into hydroxyapatite. Similar results have been obtained (Doublier et al., 2011) which showed that the quality of bone mineralization (density and heterogeneity at tissue level) was preserved after a long-term treatment with strontium ranelate. By contrast, a similar in vitro study underlines a potential physicochemical interference by Sr with HAP formation and crystal properties (Verberckmoes et al., 2004).

In our investigation, we consider at least two very different preparation procedures related to physiological and pathological calcifications. In physiological calcifications, cells are at the core of their formation while in pathological calcifications, such as kidney stones, a simple supersaturation process explains their pathogenesis. For physiological calcifications, their formations are made in a confined space while the building process of concretions occurred under a fluid circulation. Finally, in both cases, the content of $\mathrm{Sr}$ is quite low. For these two kinds of calcifications, the contribution of $\mathrm{Sr}$ atoms in X-ray fluorescence spectra are quite small (around 500 p.p.m.). Taking into account these similarities and differences, it is quite interesting to stress that the localization of $\mathrm{Sr}^{2+}$ cations in biological apatites is basically the same. By contrast, the literature seems to show that for synthetic apatites, the localization of $\mathrm{Sr}^{2+}$ cations depends of the preparation procedure. Based on this study, we may suppose that, for supplementation of $\mathrm{Sr}$ at low concentration, $\mathrm{Sr}^{2+}$ cations are localized into the apatite network.

\section{Conclusion}

Even if strontium ranelate has also shown anti-fracture efficacy in the treatment of a major health public problem, namely osteoporosis, little is known regarding the environment of Sr in biological apatites. Moreover, it is quite difficult to obtain such information based on the literature regarding the relationship between $\mathrm{Sr}^{2+}$ cations and synthetic apatites, such a relationship being strongly dependent on the preparation procedure.

In this work, biological apatites have been investigated through XANES-EXAFS spectroscopy and a set of numerical simulations using the FEFF9 program, taking into account local lattice distortion, $\mathrm{Ca}^{2+} / \mathrm{Sr}^{2+}$ substitution or the presence of cationic vacancies, have been performed. The complete set of experimental data collected on 17 samples seems to indicate that there is no relationship between the nature of the calcification (physiological and pathological) and the adsorption mode of $\mathrm{Sr}^{2+}$ cations (simple adsorption or insertion). Also, the existence of $\mathrm{Sr}-\mathrm{Ca}$ or $\mathrm{Sr}-\mathrm{Sr}$ interatomic distances seems to show that $\mathrm{Sr}^{2+}$ cations are inserted into the apatite network, a result in line with previous investigations performed on synthetic and biological apatites (Seward et al., 1999; Martin et al., 2012; Rey et al., 2007; Bazin et al., 2012).

This work was supported by the Physics and Chemistry Institutes of the CNRS, the Fondation pour la Recherche Médicale (grant DV020081013483 'Vieillissement ostéoarticulaire' 2008-2011, Pr Lioté), the Association Rhumatisme et Travail (ART), the Association 'Cristaux et Cartilage', PTD, the Association pour la Recherche en Pathologie Synoviale (ARPS) and by the Centre National de la Recherche Scientifique (CalArthros project 'Longévité et Vieillissement 2010' CNRS interdisciplinary program) and the Agence Nationale Research (France) (contract ANR-09-BLAN-0120-02). The authors declare that the study sponsors have no role in the study design, collection, analysis and interpretation of data, in the writing of the manuscript and in the decision to submit the manuscript for publication. The authors wish to thank the other members of the DIFFABS beamline team, Filipe Alves and Cristian Mocuta, for their help during synchrotron experiments.

\section{References}

Bazin, D., Carpentier, X., Brocheriou, I., Dorfmuller, P., Aubert, S., Chappard, C., Thiaudière, D., Reguer, S., Waychunas, G., Jungers, P. \& Daudon, M. (2009b). Biochimie, 91, 1294-1300.

Bazin, D., Carpentier, X., Traxer, O., Thiaudière, D., Somogyi, A., Reguer, S., Waychunas, G., Jungers, P. \& Daudon, M. (2008). J. Synchrotron Rad. 15, 506-509.

Bazin, D., Chappard, Ch., Combes, Ch., Carpentier, X., Rouzière, S., André, G., Matzen, G., Allix, M., Thiaudière, D., Reguer, S., Jungers, P. \& Daudon, M. (2009a). Osteoporos. Int. 20, 1065-1075. Bazin, D. \& Daudon, M. (2012). J. Phys. D, 45, 383001.

Bazin, D., Daudon, M., Chappard, C., Rehr, J. J., Thiaudière, D. \& Reguer, S. (2011). J. Synchrotron Rad. 18, 912-918.

Bazin, D., Daudon, M., Chevallier, P., Rouzière, S., Elkaim, E., Thiaudière, D., Fayard, B., Foy, E., Albouy, P. A., André, G., Matzen, G. \& Véron, E. (2006). Ann. Biol. Clin. 64, 125-139. 
Bazin, D., Daudon, M., Combes, Ch. \& Rey, Ch. (2012). Chem. Rev. 112, 5092-5120.

Bazin, D. \& Rehr, J. (2003). Catal. Lett. 87, 85-90.

Bigi, A., Boanini, E., Capuccini, C. \& Gazzano, M. (2007). Inorg. Chim. Acta, 360, 1009-1016.

Bigi, A., Foresti, E., Gandolfi, M., Gazzano, M. \& Roveri, N. (1995). J. Inorg. Biochem. 58, 49-58.

Bonhomme, C., Gervais, C., Babonneau, F., Coelho, C., Pourpoint, F., Azaïs, T., Ashbrook, S. E., Griffin, J. M., Yates, J. R., Mauri, F. \& Pickard, C. J. (2012). Chem. Rev. 112, 5733-5779.

Capuccini, C., Torricelli, P., Boanini, E., Gazzano, M., Giardino, R. \& Bigi, A. (2009). J. Biomed. Mater. Res. A, 89, 594-600.

Carpentier, X., Bazin, D., Jungers, P., Reguer, S., Thiaudière, D. \& Daudon, M. (2010). J. Synchrotron Rad. 17, 374-379.

Cortet, B. (2011). Curr. Osteoporos. Rep. 9, 25-30.

Daudon, M., Bazin, D., André, G., Jungers, P., Cousson, A., Chevallier, P., Véron, E. \& Matzen, G. (2009). J. Appl. Cryst. 42, 109-115.

Daudon, M., Jungers, P. \& Bazin, D. (2008). N. Engl. J. Med. 359, 100102.

Dessombz, A., Bazin, D., Dumas, P., Sandt, C., Sule-Suso, J. \& Daudon, M. (2011). PLos ONE, 6, e28007.

Dessombz, A., Méria, P., Bazin, D. \& Daudon, M. (2012). PLos ONE, 7, e51691.

Dessombz, A., Nguyen, Ch., Ea, H. K., Rouzière, S., Foy, E., Hannouche, D., Réguer, S. Picca, F. E., Thiaudière, D., Lioté, F., Daudon, M. \& Bazin, D. (2013). J. Trace Elem. Med. Biol. In the press.

Doublier, A., Farlay, D., Khebbab, M. T., Jaurand, X., Meunier, P. J. \& Boivin, G. (2011). Eur. J. Endocrinol. 165, 469-476.

Eichert, D., Salomé, M., Banu, M., Susini, J. \& Rey, C. (2005). Spectrochim. Acta B, 60, 850-858.

Elliott, J. C. (1994). Structure and Chemistry of the Apatites and Other Calcium Orthophosphates. Amsterdam: Elsevier.

Estepa, L. \& Daudon, M. (1997). Biospectroscopy, 3, 347-369.

Gomes, S., Nedelec, J. M., Jallot, E., Sheptyakov, D. \& Renaudin, G. (2011). Chem. Mater. 23, 3072-3085.

Gomes, S., Nedelec, J. \& Renaudin, G. (2012). Acta Biomater. 8, 11801189.

Guinier, A. (1956). X-ray Diffraction in Crystals Imperfect Crystals and Amorphous Bodies. Paris: Dunod.

Ibrahim, D. M., Mostafa, A. A. \& Korowash, S. I. (2011). Chem. Cent. J. 5, 74.

Kanakamani, J. \& Tandon, N. (2008). Ind. J. Rheumatol. 3, 148-157.

Korbas, M., Rokita, E., Meyer-Klaucke, W. \& Ryczek, J. (2004). J. Biol. Inorg. Chem. 9, 67-76.

Laurencin, D., Almora-Barrios, N., de Leeuw, N. H. \& Gervais, Ch. (2011). Biomaterials, 3, 1826-1837.

Li, C., Paris, O., Siegel, S., Roschger, P., Paschalis, E. P., Klaushofer, K. \& Fratzl, P. (2010). J. Bone Miner. Res. 25, 968-975.

McKeown, D. A., Kot, W. K. \& Pegg, I. L. (2003). J. Non-Cryst. Solids, 317, 290-300.

McRae, R., Bagchi, P., Sumalekshmy, S. \& Fahrni, C. J. (2009). Chem. Rev. 109, 4780-4827.

Marie, P. J. (2005). Curr. Opin. Pharmacol. 5, 633-636.

Marie, P. J. (2007). Bone, 40, S5-S8.

Martin, R. A., Twyman, H. L., Rees, G. J., Barney, E. R., Moss, R. M., Smith, J. M., Hill, R. G., Cibin, G., Charpentier, T., Smith, M. E., Hanna, J. V. \& Newport, R. J. (2012). J. Mater. Chem. 22, 22212.

Meunier, P. J., Roux, C., Seeman, E., Ortolani, S., Badurski, J. E., Spector, T. D., Cannata, J., Balogh, A., Lemmel, E., Pors-Nielsen, S., Rizzoli, R., Genant, H. K. \& Reginster, J. (2004). N. Engl. J. Med. 350, 459-468.

Mimura, H., Handa, S., Kimura, T., Yumoto, H., Yamakawa, D. \& Yokoyama, H. (2012). Nat. Phys. 6, 122-125.

Moonen, J., Slot, J., Lefferts, L., Bazin, D. \& Dexpert, H. (1995). Physica B, 208-209, 689-690.
Moyad, M. A. (2003). Urol. Oncol. Semin. Orig. Investig. 21, 375379.

Murata, H., Shitara, K., Tanaka, I., Nakahira, A., Mizoguchi, T. \& Matsunaga, K. (2012). J. Phys. Condens. Matter, 22, 384213.

Nguyen, C., Ea, H. K., Thiaudiere, D., Reguer, S., Hannouche, D., Daudon, M., Lioté, F. \& Bazin, D. (2011). J. Synchrotron Rad. 18, 475-480.

O'Day, P. A., Newville, M., Neuhoff, P. S., Sahai, N. \& Carroll, S. A. (2000). J. Colloid Interface Sci. 222, 184-197.

O’Donnell, M. D. \& Hill, R. G. (2010). Acta Biomater. 6, 2382 2385.

Palmer, B. J., Pfund, D. M. \& Fulton, J. L. (1996). J. Phys. Chem. 100, 13393-13398.

Pan, H. B., Li, Z. Y., Lam, W. M., Wong, J. C., Darvell, B. W., Luk, K. D. \& Lu, W. W. (2009a). Acta Biomater. 5, 1678-1685.

Pan, H., Li, Z., Wang, T., Lam, W. M., Wong, C. T., Darvell, B. W., Luk, K. D. K., Hu, Y. \& Lu, W. W. (2009b). Cryst. Growth Des. 9 , 3342-3345.

Penel, G., Leroy, G., Rey, C. \& Bres, E. (1998). Calcif. Tissue Int. 63, 475-481.

Persson, I., Sandström, M., Yokoyama, H. \& Chaudhry, M. (1995). Z. Naturforsch. A, 50, 21-30.

Pinkerton, J. V. \& Dalkin, A. C. (2007). Am. J. Obstet. Gynecol. 197, 559-565.

Pizzala, H., Caldarelli, S., Eon, J. G., Rossi, A. M., San Gil, R. A., Laurencin, D. \& Smith, M. E. (2009). J. Am. Chem. Soc. 131, 51455152.

Ravi, N. D., Balu, R. \& Sampath Kumar, T. S. (2012). J. Am. Ceram. Soc. 95, 2700-2708.

Rehr, J. J., Kas, J. J., Prange, M. P., Sorini, A. P., Takimoto, Y. \& Vila, F. (2009). C. R. Phys. 10, 548-559.

Revel, R., Bazin, D., Elkaim, E., Kihn, Y. \& Dexpert, H. (2000). J. Phys. Chem. B, 104, 9828-9835.

Rey, C., Combes, C., Drouet, C., Sfihi, H. \& Barroug, A. (2007). Mater. Sci. Eng. 27, 198-205.

Rey, C., Miquel, J. L., Facchini, L., Legrand, A. P. \& Glimcher, M. J. (1995). Bone, 16, 583-586.

Rochefort, G. Y., Pallu, S. \& Benhamou, C. L. (2010). Osteoporos. Int. 21, 1457-1469.

Rokidi, S. \& Koutsoukos, P. G. (2012). Chem. Eng. Sci. 77, 157164.

Romieu, G., Garric, X., Munier, S., Vert, M. \& Boudeville, Ph. (2006). Acta Biomater. 6, 3208-3215.

Sayers, D. A., Lytle, F. W. \& Stern, E. A. (1970). Advances in X-ray Analysis. New York: Plenum.

Sayers, D. A., Stern, E. A. \& Lytle, F. W. (1971). Phys. Rev. Lett. 27, 1204-1207.

Sepulcre, F., Proietti, M. G., Benfatto, M., Della Longa, S., García, J. \& Padrós, E. (2004). Biophys. J. 87, 513-520.

Seward, T., Henderson, C., Charnock, J. \& Driesner, T. (1999). Geochim. Cosmochim. Acta, 63, 2409-2418.

Tang, Y., Chappell, H. F., Dove, M. T., Reeder, R. J. \& Lee, Y. J. (2009). Biomaterials, 30, 2864-2872.

Terra, J., Dourado, E. R., Eon, J. G., Ellis, D. E., Gonzalez, G. \& Rossi, A. M. (2009). Phys. Chem. Chem. Phys. 11, 568-577.

Vallet-Reg1, M. \& Gonzalez-Calbet, J. M. (2002). Prog. Solid State Chem. 32, 1-31.

Verberckmoes, S. C., Behets, G. J., Oste, L., Bervoets, A. R., Lamberts, L. V., Drakopoulos, M., Somogyi, A., Cool, P., Dorriné, W., De Broe, M. E. \& D'Haese, P. C. (2004). Calcif. Tissue Int. 75 405-415.

Yachandra, V. K. \& Yano, J. (2011). J. Photochem. Photobiol. B, 104, 51-59.

Yu, M., Tian, S., Chu, W., Chen, D., Wang, Q. \& Wu, Z. (2009). J. Synchrotron Rad. 16, 528-532.

Zhang, C., Cheng, Z., Yang, P., Xu, Z., Peng, C., Li, G. \& Lin, J. (2009). Langmuir, 25, 13591-13598. 